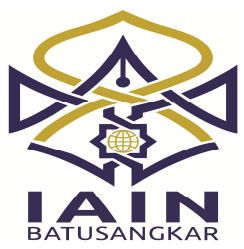

JURNAL TA'DIB, Volume 20 (1), 2017, (Januari-Juni)

(Cetak ISSN 1410-8208 Online ISSN 1410-8208)

Tersedia online di http://ecampus.iainbatusangkar.ac.id/ojs/index. php/takdib/index

\title{
Development of A Thinking Skill Teaching Model in Disain Pembelajaran Subject
}

\author{
Susi Herawati *) \\ Institut Agama Islam Negeri Batusangkar, \\ Sumatera Barat, Indonesia \\ E-mail: susiherawati2642@gmail.com
}

\section{Najmiatul Fajar*}

Institut Agama Islam Negeri Batusangkar, Sumatera Barat, Indonesia

E-mail: najmiatulf004@gmail.com

\begin{abstract}
Abstrak: The thinking skill teaching model which is based on metacognitive theory is a teaching method that requires students' skills in managing and controlling themselves to develop their thinking ability. The developed thinking skill model refers to four types of skills, namely problem-solving skills, decision-making skills, critical and creative thinking skills. The teaching model is developed to teach students' thinking ability. This is a research and development study that adopts Borg \& Gall (1989) steps consisting of four stages, namely (1) Collecting information (including literature review, observation of existing tools and creating research framework); (2) Designing (formulating research objectives, estimating funds and time required and research work procedures); (3) Developing initial product form (initial draft of product design); and (4) conducting initial field trials. Based on the result of the research, it is found that 1) the developed thinking skill model is the research that tries to develop a learning model to develop and improve students' thinking ability, 2) the theoretical foundation of the development of this thinking skill model is metacognitive theory, 3) the product validation result generated, in the form of modules and assessment instruments, is in valid category, because the products produced is in line with the theoretical basis used, 4) based on the practicality of the product, in the form of modules and valuation instruments, it was found that it is in the practical category, meaning that the resulted product is applicable in teaching students' thinking capability.
\end{abstract}

Key Words : Teaching model development, Thinking skills, Disain pembelajaran.

\section{PENDAHULUAN}

Standar Proses Pendidikan
sebagaimana yang tertuang pada
Permendikbud no. 49 tahun 2014 Pasal
11 ayat 1 yaitu yaitu yang berkaitan
dengan standar proses pembelajaran yaitu
interaktif, holistik, integratif, saintifik,
kontekstual, tematik, efektif, kolaboratif,
dan berpusat pada mahasiswa. Standar
proses tersebut merupakan acuan bagi
pendidik/ dosen dalam pembelajaran.
Dimana untuk mencapai standar proses
tersebut didukung juga oleh model,
strategi dan metode pembelajaran yang
digunakan. Standar perkuliahan seperti

yang tergambar pada standar nasional pendidikan tersebut dapat dilaksanakan dengan beberapa komponen model perkuliahan yang berorientasi pada mahasiswa, diantaranya model discovery learning, cooperative learning, problem based learning, dan lain-lain. Dengan menerapkan model-model tersebut diharapkan mahasiswa mampu memecahkan masalah, mengambil keputusan. berfikir kritis, dan kreatif.

Beberapa keterampilan berfikir tersebut juga diperlukan dalam mata kuliah disain pembelajaran. Mata kuliah disain pembelajaran adalah mata kuliah yang menuntut mahasiswa untuk 
mengembangkan keempat kemampuan tersebut karena sasaran mata kuliah disain pembelajaran adalah mahasiswa dapat merancang perangkat disekolah. Pada dasarnya proses perkuliahan yang terjadi selama ini di IAIN Batusangkar sudah berorientasi pada mahasiswa, sudah menggunakan berbagai model pembelajaran yang berorientasi pada mahasiswa, tetapi masih banyak mahasiswa yang belum mampu memecahkan masalah, mengambil keputusan, berfikir kritis, dan kreatif. Ini terlihat ketika berdiskusi masih ada mahasiswa yang tidak mampu menjawab beberapa pertanyaan, tidak mampu mengkritisi, tidak mampu menganalisa pertanyaan. Hanya beberapa mahasiswa yang mampu menjawab pertanyaan, mengkritisi makalah temannya. Hal ini juga terlihat dari jawaban soal yang diberikan ketika ujian mid semester, banyak mahasiswa yang tidak mampu mengaitkan satu konsep dengan konsep lainnya, serta tidak mampu memecahkan masalah yang diajukan dalam soal. Fenomena ini juga terlihat ketika mahasiswa menulis proposal skripsi, hampir semua mahasiswa PAI kesulitan mengumpulan fakta yang terkait dengan objek yang diteliti, kurang mampu menganalisis informasi, serta tidak mampu menyusun berbagai alternatif pemecahan, dan memilih pemecahan masalah yang tepat.

Untuk mengatasi permasalahan ini perlu kiranya dirancang suatu model pembelajaran yang dapat membimbing mahasiswa agar dapat memecahkan masalah, mengambil keputusan, serta berfikir kritis dan kreatif. Untuk itu penelitian ini berusaha untuk mengembangkan suatu model pembelajaran yaitu dengan mengembangkan model pembelajaran yang mampu mengembangkan kemampuan pemecahan masalah, kemampuan pegambilan keputusan, kemampuan berfikir kritis dan kreatif. Berdasarkan permasalahan di atas maka rumusan masalah penelitian ini adalah 1) bagaimanakah pengembangan model pembelajaran keterampilan berfikir dalam mata kuliah disain pembelajaran? 2) bagaimanakah validitas dan praktikabilitas model pembelajaran keterampilan berfikir dalam mata kuliah disain pembelajaran? . Untuk itu tujuan penelitian ini adalah menghasilkan model pembelajaran keterampilan berfikir dalam mata kuliah disain pembelajaran dengan sasaran 1) menghasilkan model pembelajaran keterampilan berfikir dalam mata kuliah disain pembelajaran, 2) untuk mengetahui validitas, dan praktikabilitas model pembelajaran keterampilan berfikir pada mata kuliah disain pembelajaran.

\section{KAJIAN TEORI}

Model adalah kerangka konseptual yang melukiskan prosedur yang sistematis dalam mengorganisasikan pengalaman belajar untuk mencapai tujuan belajar tertentu, dan berfungsi sebagai pedoman bagi para perancang pembelajaran dan para pengajar dalam merencanakan aktivitas belajar mengajar (Trianto; 22). Sebagai kerangka konseptual model pembelajaran menjadi dasar bagi perancang untuk merencanakan proses pembelajaran sesuai dengan sasaran yang diinginkan sehingga tujuan tercapai secara efektif dan efisien. Kesimpulannya model pembelajaran adalah pola yang digunakan perancang untuk pedoman yang dapat digunakan di kelas/ atau pada situasi tertentu.

Model keterampilan berfikir adalah pola yang digunakan perancang untuk mengembangkan proses pembelajaran agar proses pembelajaran tersebut tercapai secara efektif dan efisien, dimana yang menjadi sasaran proses pembelajaran adalah mahasiswa dapat mengembangkan keterampilan berfikirnya.

Pengembangan model keterampilan berfikir ini didasarkan teori metakognitif dimana metakognitif adalah seperti yang dikutip oleh Pannen (1996) dari Preisseisen adalah merupakan 
keterampilan maahasiswa dalam mengatur dan mengontrol proses berfikirnya. Artinya keterampilan ini membutuhkan pengaturan dan pengontrolan oleh mahasiswa itu sendiri untuk mengembangkan kemampuan berfikirnya.

Kemampuan berfikir tidak dapat dipisahkan dari kemampuan mengingat dan memahami, sebagaimana teori mengenai berfikir dalam Sanjaya; 2006 menurut Peter Reason, berfikir adalah proses mental seseorang yang lebih dari sekedar mengingat dan memahami, berfikir membuat seseorang bergerak diluar informasi yang didengar, pada akhirnya seseorang dapat memecahkan masalah.

Ada empat jenis keterampilan yang dikemukakan oleh Preisseissen dalam Panen (1996) yaitu keterampilan pemecahan masalah, keterampilan pengambilan keputusan, keterampilan berfikir kritis, dan keterampilan berfikir kreatif. Lebih lanjut rincian keterampilan berfikir ini menurut Preisseisen dalam Panen (1997) meliputi empat jenis keterampilan yaitu keterampilan pemecahan masalah adalah keterampilan individu dalam menggunakan proses berfikirnya untuk memecahkan masalah melalui pengumpulan fakta-fakta, analisis informasi, menyusun berbagai alternatif pemecahan, dan memilih pemecahan masalah yang tepat. Kemampuan pengambilan keputusan adalah keterampilan individu dalam menggunakan proses berfikirnya untuk memilih suatu keputusan yang terbaik dari berbagai pilihan yang ada melalui pengumpulan informasi, perbandingan kebaikan dan kekurangan dari setiap alternative, analisis informasi, dan pengambilan keputusan yang terbaik berdasarkan alasan-alasan yang rasional. Sedangkan keterampilan berfikir kritis adalah keterampilan individu dalam menggunakan proses berfikirnya untuk menganalisis argument dan memberikan interpretasi berdasarkan persepsi yang sahih melalui logical reasoning, analisis asumsi dan bias dari argument, dan interpretasi logis. Sedangkan keterampilan berfikir kreatif adalah keterampilan individu dalam menggunakan proses berfikirnya untuk menghasilkan suatu ide yang baru, konstruktif, dan baik berdasarkan konsep-konsep, dan prinsipprinsip yang rasional maupun persepsi, dan intuisi individu.

Pengembangan model pembelajaran ini adalah mencoba merancang dan mengembangkan model pembelajaran yang mengacu pada teori metakognitif agar mahasiswa dapat mengembangkan kemampuan berfikirnya. Model yang dirancang ini meliputi tujuan, sintak, lingkungan dan system pengelolaanya sebagaimana yang dikemukan oleh Arend dalam Trianto ( 2009) bahwa ciri-ciri model itu adalah 1) rasional teoritis logis yang disusun oleh pencipta atau pengembangnya,2) landasan tentang apa dan bagaimana siswa belajar ( tujuan yang akan dicapai), 3) tingkah laku belajar yang diperlukan agar model tersebut dapat dilaksanakan dengan berhasil,4) lingkungan belajar yang diperlukan agar tujuan pembelajaran tercapai.

Ciri-ciri Model Keterampilan Berfikir

1) Landasan teori yang digunakan adalah teori metakognitif, dimana teori ini dapat membimbing mahasiswa untuk mengembangkan kemampuan berfikirnya. Sesuai dengan mata kuliah yang akan dikembangkan model pembelajarannya, bahwa mata kuliah disain pembelajaran sasarannya lebih banyak pada pengembangan kognitif, terutama pada level analisis, sintesis, dan evaluasi, maka teori metakognitif tepat dipilih sebagai landasan pengembangan model keterampilan berfikir.

2) Landasan tentang apa dan bagaimana mahasiwa belajar juga mengacu pada pembelajaran kognitif serta paradigma konstruktivisme, sebagaimana menurut kaum konstruktivisme bahwa belajar adalah proses aktif pelajar mengkonstruksi arti entah teks, dialog, 
pengalaman fisis, dan lain-lain, belajar juga adalah proses mengasimilasi, dan menghubungkan pengalaman dan bahan yang akan dipelajari dengan pengalaman yang sudah dimiliki sebelumnya. Lebih lanjut tergambar dari proses pembelajaran itu sendiri sebagaimana yang dijelaskan Fosnot (1996) yang dikutip oleh Suparno (1997) Belajar bukanlah hanya kegiatan mengumpulkan fakta, melainkan lebih kepada pengembangan pemikiran dengan membuat pengertian baru. Sedangkan mengajar menurut kaum konstruktivis dalam Suparno (1997) mengajar adalah berpartisipasi dengan pelajar dalam membentuk pengetahuan, membuat makna, mencari kejelasan, bersikap kritis, dan mengadakan justifikasi.

3) Tingkah Laku belajar yang diperlukan agar tujuan dapat tercapai adalah adanya kesadaran mahasiswa bahwa belajar merupakan kesadaran inividu untuk mengontrol dan mengatur kemampuan berfikirnya, bukan sekedar mengingat dan memahami suatu informasi saja, untuk itu perlu dirancang sumber pendukung agar terbentuknya tingkah laku untuk mengembangkan keterampilan berfikir, dalam hal ini peneliti mengembangkan sumber belajar dalam bentuk modul serta instrumen untuk mengukur ketercapaian keterampilan berfikir tersebut.

4) Lingkungan yang dapat mendukung tercapainya tujuan, dalam hal ini peneliti memilih materi yang bersifat prosedur dan praktek agar tujuan pembelajaran dapat tercapai.

Modul pembelajaran adalah paket belajar mandiri yang mempunyai karakteristik tertentu sesuai dengan kebutuhan sasaran pembelajaran. Sebagaimana yang didefinisikan oleh Russel dalam made wena ( 2009) adalah suatu paket pembelajaran yang berisi satu unit konsep tunggal. Sedangkan Houston
\& Hoeson mengemukakan modul pembelajaran meliputi seperangkat aktivitas yang mempermudah siswa untuk mencapai tujuan. (Wena; 230: 2009). Definisi modul menurut pusat teknologi informasi.dan komunikasi pendidikan adalah bahan belajar yang dirancang secara sistematis berdasarkan kurikulum tertentu dan dikemas dalam bentuk satuan pembelajaran terkecil dan memungkinkan untuk belajar secara mandiri $(9 ; 2007)$.

Berdasarkan beberapa pandangan tentang modul pemebelajaran di atas dapat disimpulkan bahwa modul pembelajaran adalah paket belajar mandiri yang mempunyai karakteristik tertentu sesuai dengan kebutuhan sasaran pembelajaran. Sebagai paket belajar mandiri fungsi modul itu sendiri adalah sebagai bahan belajar yang digunakan dalam kegiatan pembelajaran, dan dapat jadi petunjuk belajar bagi peserta didik (Pustekom h.9;2007).

Banyak pendapat tentang komponen/ unsur-unsur modul, pada dasarnya sebagaimana yang dikemukakan oleh wena (2009) adalah :a) modul merupakan seperangkat pembelajaran yang berdiri sendiri, b) modul gunanya untuk memudahkan siswa mencapai tujuan, c) modul merupakan suatu unit-unit yang berhubungan satu sama lain secara hirarkis.

Berdasarkan unsur-unsur di atas maka modul yang dirancang terdiri dari komponen petunjuk penggunaan, Lembar Kegiatan, Lembar Kerja, Materi, serta Soal. Sesuai dengan apa yang dikemukakan oleh Suryosubroto dalam Wena ( 233:2009) Komponen-komponen modul itu terdiri dari i) pedoman guru, ii)lembar kegiatan siswa, iii) lembar kerja, iv) kunci lembaran kerja,v) lembaran tes,vi) kunci lembaran tes.

Instrumen penilaian adalah alat ukur yang digunakan untuk mengukur kemampuan tertentu. Instrumen penilaian yang tepat akan menghasilkan pengukuran yang tepat , sebagaimana yang dikemukakan yang tertuang dalam definisi 
evaluasi dan proses yang dilakukan dalam evaluasi yaitu mengukur dan menilai. Sebagaimana berkaitan dengan konsep mengukur adalah membandingkan sesuatu dengan satu ukuran, dimana pengukuran tersebut bersifat kuantitatif, menilai adalah mengambil suatu keputusan terhadap suatu ukuran, dimana penilaian bersifat kualitatif ( herawati; 2012)

Berdasarkan penjelasan di atas perlu dirancang alat ukur yang tepat sesuai dengan yang akan dikur. Dalam hal ini peneliti akan merancang instrumen penilaian praktek mendisain pembelajaran yang dapat digunakan untuk mengukur keterampilan berfikir mahasiswa.Instrumen penilaian praktek ini sama dengan tes perbuatan.

Menurut Yusuf; 2005 langkahlangkah merancang instrumen penilaian perbuatan adalah 1) susunlah keterampilan dan kemampuan khusus yang terlibat dalam kegiatan tertentu yang akan diukur, 2) pilih keterampilan yang akan diuji diantara keterampilan yang telah ditetapkan, 3) tetapkan aspek karakteristik aspek yang diukur.

Instrumen penilaian praktek mendisain pembelajaran yang akan dirancang mengacu pada indikator keterampilan berfikir yang meliputi kemampuan memecahkan masalah, kemampuan mengambil keputusan, kemampuan berfikir kritis dan kreatif sebagaimana rinciannya pada teori keterampilan berfikir.

Disain pembelajaran adalah adalah proses penyusunan langkah-langkah pengembangan pembelajaran dalam rangka mengarahkan pembelajar mendapatkan pengalaman belajar, berdasarkan tujuan yang telah ditetapkan.

Disain pembelajaran sebagai mata kuliah adalah salah satu mata kuliah keahlian dan keterampilan yang wajib diikuti oleh seluruh mahasiswa pada jurusan Tarbiyah. Mata kuliah ini juga merupakan mata kuliah prasyarat sebelum mahasiswa mengikuti mikro teaching dan praktek pengalaman lapangan ( PPL ) di sekolah. Disamping itu ada beberapa mata kuliah yang disyaratkan untuk diikuti mahasiswa terlebih dahulu sebelum mereka mengikuti mata kuliah disain pembelajaran diantara mata kuliah yang disyaratkan adalah mata kuliah pengembangan kurikulum, mata kuliah strategi dan metode pembelajaran, mata kuliah media pembelajaran, serta mata kuliah evaluasi pembelajaran.

Beberapa mata kuliah yang disyaratkan tersebut minimal sudah pernah diikuti oleh mahasiswa yang akan kuliah mata kuliah disain pembelajaran, karena tanpa ada pengetahuan awal untuk mengikuti perkuliahan disain pembelajaran ini mahasiswa kesulitan memahami materi, dan kesulitan mendisain perangkat pembelajaran.

Secara umum tujuan mata kuliah disain pembelajaran adalah mahasiswa dapat memahami konsep dasar disain pembelajaran serta komponenkomponennya dan mampu mengaplikasikannya dalam bentuk perancangan perangkat pembelajaran di Sekolah dan Madrasah. Secara khusus sasaran pembelajaran ini adalah mahasiswa mampu mendisain perangkat pembelajaran.

Kemampuan mendisain (merancang) adalah termasuk taksonomi kognitif, menurut kategori bloom level ini adalah level tertinggi dari kemampuan berfikir mahasiswa. Level tertinggi ini bisa dicapai oleh mahasiswa jika mahasiswa mampu menguasai kemampuan berfikir level sebelumnya yaitu kemampuan analisis, dan sintesis. Kaitan ranah kognitif dengan mata kuliah disain pembelajaran ini adalah, mahasiswa harus mampu memahami konsep dasar disain pembelajaran yang meliputi pengetahuan mahasiswa tentang komponen disain pembelajaran diantaranya tujuan, materi, strategi, media dan evaluasi pembelajaran dimana beberapa komponen tersebut harus dipahami mahasiswa sebagai suatu sistem yang saling berkaitan (kemampuan analisis), serta mahasiswa harus 
memahami komponen disain tersebut secara terpisah dan masing-masing komponen mempunyai fungsi masingmasing (kemampuan sintesis).

Ruang lingkup mata kuliah disain pembelajaran secara umum meliputi konsep disain pembelajaran serta praktek merancang perangkat pembelajaran secara rinci ruang lingkup mata kuliah disain pembelajaran meliputi: Pertama, pengertian, tujuan, manfaat disain pembelajaran. Kedua, model-model disain pembelajaran komponen-komponen disain pembelajaran. Ketiga, langkah mendisain program tahunan dan semester. Keempat, langkah mendisain tujuan pembelajaran. Kelima, langkah mendisain materi pembelajaran. Keenam, langkah mendisain strategi pembelajaran. Ketujuh, langkah mendisain media pembelajaran. Kedelapan, langkah mendisain evaluasi pembelajaran. Kesembilan, langkah mendisain Perangkat Pembelajaran

\section{METODE PENELITIAN}

Metode penelitian yang digunakan adalah penelitian dan pengembangan (research and develpoment) yaitu suatu penelitian yang dimaksudkan untuk mengembangkan suatu produk berupa model pembelajaran kemampuan berfikir untuk pada mata kuliah disain pembelajaran PAI IAIN Batusangkar. Sebagaimana yang dikemukakan oleh Van den Akker dan Plomp ( 1999) bahwa karakteristik penelitian pengembangan bertujuan untuk mengembangkan produk termasuk kurikulum serta perangkat yang dibutuhkan dalam pembelajaran.

Dalam penelitian pengembangan ini peneliti akan mengembangkan model pembelajaran keterampilan berfikir dengan mengikuti langkah-langkah research and development Borg \& Gall yaitu (1) Melakukan pengumpulan informasi (termasuk kajian pustaka, pengamatan terhadap perangkat yang ada, membuat kerangka kerja penelitian); (2) Melakukan perancangan (merumuskan tujuan penelitian, memperkirakan dana dan waktu yang diperlukan, prosedur kerja penelitian); (3) Mengembangkan bentuk produk awal (perancangan draf awal produk); (4) Melakukan ujicoba lapangan permulaan; (5) Melakukan revisi terhadap produk utama; (6) Melakukan ujicoba lapangan utama; (7) Melakukan revisi terhadap uji lapangan utama; Melakukan uji lapangan operasional; (9) Melakukan revisi terhadap produk akhir; (10) Mendesiminasikan dan mengimplementasikan produk (Borg \& Gall :785:1989).

Adapun tahapan yang dilakukan dalam penelitian pengembangan ini meliputi:

1. Analisis Produk.

Analisis produk meliputi pengumpulan informasi yang terkait dengan mahasiswa yang mengikuti mata kuliah disain pembelajaran dengan menganalisis kebutuhan dan karakteristinya. Serta melakukan kajian teori terkait dengan model yang dikembangkan. Langkah ini juga disertai dengan menganalisis silabus mata kuliah disain pembelajaran untuk melihat materi yang terkait dengan model yang dikembangkan. Analisis kebutuhan dan karakteristik mahasiswa yang mengikuti mata kuliah disain pembelajara dengan melakukan wawancara dan observasi terhadap proses perkuliahan.

2. Mengembangkan produk awal.

Langkah selanjutnya adalah mengembangkan model pembelajaran keterampilan berfikir berdasarkan hasil analisis kebutuhan, karakteristik, serta kajian teori yang terkait dengan model yang dikembangkan dan juga berdasarkan hasil analisis terhadap silabus. Produk yang dirancang yaitu modul serta instrumen penilaian praktek dengan mengacu pada model pembelajaran keterampilan berfikir.

3. Validasi ahli.

Tahap berikutnya adalah validasi expert / ahli terhadap produk yang sudah dihasilkan berupa Modul, dan 
instrumen penilaian praktek yang mengacu pada karakteristik model. Validasi produk berupa Modul mengacu pada isi modul, karakteristik modul, serta kesesuaian bahasa yang digunakan. Sedangkan intrumen penilaian praktek yang akan divalidasi mengacu pada kesesuaian aspek keterampilan berfikir dan kesesuain aspek penilaian praktek mendisain pembelajaran dengan model yang dikembangkan. Produk yang sudah dirancang diberikan pada yang berkompeten dibidang disain pembelajaran dan evaluasi yang terdiri dari tiga orang validator.

4. Revisi Produk

Produk berupa modul dan istrumen penilaian praktek yang sudah dirancang divalidasi oleh 3 orang validator untuk memberikan masukan dari produk yang sudah dirancang. Saran dan masukan validator dijadikan sebagai masukan pada tahap revisi produk.

\section{HASIL PENELITIAN DAN PEMBAHASAN}

1. Gambaran kemampuan keterampilan berfikir mahasiswa.

Berdasarkan hasil wawancara dengan dosen yang mengajar di jurusan PAI bahwa mahasiswa kesulitan menjawab pertanyaan yang membutuhkan jawaban yang lebih rinci, kesulitan mengaitkan beberapa konsep, mengkritisi. Fenomena ini juga terlihat ketika mahasiswa menulis proposal skripsi, mahasiswa kesulitan mengaitkan satu konsep dengan konsep lain, kesulitan membuat kesimpulan,serta tidak mampu membuat suatu argument dari pendapat sendiri. Indikasi-indikasi tersebut mengindikasikan terjadinya ketidak mampuan mahasiswa untuk mengembangkan keterampilan berfikirnya.

Keterampilan berfikir adalah terkait dengan pengerahan aspek kognitif seseorang, seperti yang dikemukakan oleh Preisseisen dalam Pannen (2007) meliputi kemampuan memecahkan masalah, kemampuan mengambil keputusan, kemampuan berfikir kritis, dan kreatif.

Keempat kemampuan di atas perlu dikembangkan dan dilatih agar keterampilan berfikir seseorang dapat maksimal digunakan terutama pada mahasiswa agar mahasiswa mampu menggunakan keterampilan berfikirnya dalam proses pembelajaran dan proses penulisan skripsi nantinya.

Kemampuan berfikir tidak dapat dipisahkan dari kemampuan mengingat dan memahami, sebagaimana teori mengenai berfikir dalam Sanjaya; 2006 menurut Peter Reason, berfikir adalah proses mental seseorang yang lebih dari sekedar mengingat dan memahami, berfikir membuat seseorang bergerak diluar informasi yang didengar, pada akhirnya seseorang dapat memecahkan masalah. Permasalahan yang terjadi pada mahasiwa pada umumnya disebabkan mereka belum terbiasa mengembangkan kemampuan berfikirnya, artinya hanya terbiasa untuk menggunakan kemampuan mengingat dan memahami saja, pada akhirnya mahasiswa tidak mampu memecahkan masalah, mengambil keputusan , bahkan berfikir kritis dan kreatif.

Keterampilan berfikir ini dapat diterapkan dalam proses pembelajaran atau perkuliahan, diantaranya dengan mengembangkan model pembelajarannya. Dalam penelitian ini peneliti berusaha untuk mengembangkan model pembelajaran keterampilan berfikir sebagaimana definisi model itu sendiri yaitu menurut Arends yang dikutip Trianto (2009:22) "The term teaching model refers to particular approach to instruction that includes its goals, 
syntax, environment, and management system". Dimana idealnya ada beberapa komponen yang harus ada pada suatu model pembelajaran yaitu tujuan, sintak, lingkungan, serta pengelolaanya.

Berdasarkan fenomena serta kajian teori maka untuk mengatasai permasalahan perlu dikembangkan model pembelajaran keterampilan berfikir dalam mata kuliah disain pembelajaran.

2. Rancangan Produk Awal

Produk yang dirancang berdasarkan teori metakognitif yaitu menurut Preisseisen yang dikutip oleh Pannen ( 1996) adalah keterampilan mahasiswa dalam mengatur dan mengontrol proses berfikirnya. Teori metakognitif dikembangkan dari paradigma kostruktivisme, dimana menurut kaum konstruktivisme bahwa belajar adalah proses aktif pelajar mengkonstruksi arti entah teks, dialog, pengalaman fisis, dan lain-lain, belajar juga adalah proses mengasimilasi, dan menghubungkan pengalaman dan bahan yang akan dipelajari dengan pengalaman yang sudah dimiliki sebelumnya. Lebih lanjut tergambar dari proses pembelajaran itu sendiri sebagaimana yang dijelaskan Fosnot ( 1996 ) yang dikutip oleh Suparno ( 1997) Belajar bukanlah hanya kegiatan mengumpulkan fakta, melainkan lebih kepada pengembangan pemikiran dengan membuat pengertian baru. Sedangkan mengajar menurut kaum konstruktivis dalam Suparno ( 1997) mengajar adalah berpartisipasi dengan pelajar dalam membentuk pengetahuan, membuat makna, mencari kejelasan, bersikap kritis, dan mengadakan justifikasi.

Berdasarkan teori metakogitif tersebut maka dikembangkan modul dan istrumen penilaian keterampilan berfikir dengan mengaju pada empat jenis keterampilan berfikir yaitu keterampilan pemecahan masalah, keterampilan pengambilan keputusan, keterampilan berfikir kritis, serta keterampilan berfikir kreatif.

Produk berupa modul keterampilan berfikir dikembangkan sesuai dengan idealnya sebuah modul, dimana modul sebagai paket belajar mandiri yang mempunyai karakteristik tertentu sesuai dengan kebutuhan sasaran pembelajaran, dalam hal ini modul yang dikembangkan yaitu modul keterampilan berfikir. Seperti yang tertuang pada spesifikasi produk bahwa pengembangan keterampilan berfikir dituangkan dalam lembar kegiatan dan kerja mahasiswa. Begitu juga dengan produk instrumen penilaian praktek yang dikembangkan penilaian keterampilan berfikir menjadi aspek yang akan dinilai yang meliputi empat jenis keterampilan berfikir.

3. Validasi Produk

Validasi sebagaimana yang dikemukakan oleh Nieeven (1999) yang dikutip oleh Trianto ( 2009) dalah tahap dimana produk yang sudah dihasilkan memenuhi kriteria shahiah artinya apakah model yang dikembangkan didasarkan pada rasional teoritis yang kuat dan terdapat konsistensi internal.

Berdasarkan hasil validasi seperti yang telah dijelaskan pada hasil penelitian bahwa produk yang dikembangkan berupa modul dan instrumen penilaian praktek sangat valid, artinya sesuai dengan kriteria Nieeven di atas produk yang dihasilkan sesuai dengan teori dan adanya konsistensi internal.

4. Praktikalitas Produk

Praktikalitas adalah sebagaimana juga yang dikemukakan oleh Nieeven (1999) yang dikutip oleh Trianto (2009) yaitu aspek kepraktisan dapat dipenuhi jika para ahli dan praktisi menyatakan bahwa apa yang dikembangkan dapat diterapkan dan 
kenyataan menunjukkan bahwa apa yang dikembangkan dapat diterapkan.

Berdasarkan hasil praktikalisasi produk sebagaimana yang telah dijelaskan pada hasil penelitian bahwa produk yang dikembangkan berupa modul dan instrumen penilaian praktek praktis, artinya sesuai dengan kriteria Nieeven di atas produk yang dikembangkan dapat diterapkan dalam mata kuliah disain pembelajaran.

\section{PENUTUP}

Berdasarkan hasil penelitian dapat disimpulkan beberapa hal yaitu:

1. Penelitian pengembangan model keterampilan berfikir ini adalah penelitian yang mencoba mengembangkan model pembelajaran yang dapat digunakan untuk mengembangkan dan meningkatkan kemampuan berfikir.

2. Landasan teori pengembangan model keterampilan berfikir ini adalah teori metakognitif.

3. Berdasarkan hasil validasi produk yang dihasilkan berupa modul dan instrumen penilaian valid, artinya produk yang dihasilkan sesuai dengan landasan teori yang digunakan.

4. Berdasarkan praktikalitas produk yang dihasilkan yaitu berupa modul dan instrumen penilaian praktis, artinya produk yang dihasilkan dapat diterapkan.

\section{DAFTAR PUSTAKA}

Borg and Gall, 1989. Educational Reseasrch : an Introduction, Fifth Edition, New York: Longman

Paulina Panen, dkk,1995. Mengajar di Perguruan

Tinggi,Jakarta:Univ.Terbuka

Permendikbud RI No.49 Tahun 2014
Sanjaya, Wina, 2006, Strategi Pembelajaran Berorientasi Standar Proses Pendidikan, Jakarta: Kencana Prenada Media

Suparno, Paul,1997, $\quad$ Filsafat Konstruktivisme Dalam Pendidikan,Jogya Karta: Kanisius

Trianto, 2009. Mendisain Model Pembelajaran Inovatif Progresif,Kencana Prenada media

Herawati, Susi, 2012. Disain Pembelajaran Kajian Teoritis dan Praktis, Batusangkar: STAIN Press

Van den Akker, J. 1999. Principles and Methods of Development Research. In J. van den Akker, R. Branch, K. Gustafson, N. Niveen, \& Tj. Plomp (Eds.), Design approaches and tools in education and training (pp. 1-14). Dordrecht: Kluwer Academic Publisher. Enschede, The Netherlands: Printpartners.

Wena, Made, 2009, Strategi Pembelajaran Inovatif Kontemporer: Suatu Tinjauan Kosensptual Operasional, Jakarta: Bumi Aksara.

Yusuf,A.Muri,2005, Dasar-dasar Evaluasi Pendidikan, Padang: UNP 